\title{
Scaffolding learners in authentic, problem based e-learning environments: The Geography Challenge
}

\author{
Gwyn Brickell and Jan Herrington \\ University of Wollongong
}

\begin{abstract}
The affordances of online learning technologies have enabled more widespread development of learning environments that facilitate the exploration and solving of complex and realistic problems. In this paper, we describe the design of a real world geography problem, embedded within a web environment that is facilitated by an onsite excursion for data collection. The learning environment has been designed to deliberately address known problems associated with the problem solving approach, specifically in regard to three issues, and uses scaffolding prompts and supports embedded within the environment to facilitate student learning. The paper describes the theoretical foundations for the approach, the design of the learning task, and specific scaffolding approaches used in the environment.
\end{abstract}

\section{III-structured problems in school learning}

Complex problems lie at the heart of most experiential and student centred learning environments (Hmelo-Silver, 2002; Jonassen, 2000; 2006). The design of complex and authentic problems has been the focus of much research and development activity over the past two decades, as teachers and designers seek to adopt more meaningful and engaging approaches to their learning environments. However, the design of a meaningful problem can be difficult if it is to enable students to learn not only content knowledge but also higher order thinking and problem solving skills (Hmelo-Silver, 2002). Such problems are not commonly found in most educational contexts, as Jonassen (2000) noted:

Virtually everyone, in their everyday and professional lives, regularly solves problems ... Unfortunately, students are rarely, if ever, required to solve meaningful problems as part of their curricula. The few problems that students do encounter are normally well-structured (story) problems, which are inconsistent with the nature of the problems they will need to learn to solve in their everyday lives. (p. 63) 
Others have argued that most set problems lack the complexity required to help students learn to use the knowledge they have acquired in appropriate and adaptive ways (e.g. Cognition and Technology Group at Vanderbilt, 1993). In dealing with simple, or well-structured problems, Collins (1988) has argued that students often invoke 'suboptimal schemes' for remembering information solely to pass tests, rather than to address the genuine demands of a real problem. 'For example, arithmetic students might conclude that any word problems including the word left (How many did she have left?) are subtraction problems ... such knowledge is less likely to be stored in a form that is useable when applied to novel situations' (pp. 2-3). In these contexts, knowledge itself is seen by learners as the final product of education rather than a tool to be used dynamically to solve problems (Cole, 1990).

Sternberg, Wagner and Okagaki (1993) analysed the differences between the kinds of problems learners face in academic situations and practical, real world applications. For example, academic problems tend to be: formulated by others, well-defined, complete in the information they provide, characterised by having only one correct answer, characterised by having only one method of obtaining the correct answer, disembedded from ordinary experience, and of little or no intrinsic interest. In direct contrast to the academic approach, practical problems tend to be characterised by: the key roles of problem recognition and definition, the ill-defined nature of the problem, substantial information seeking, multiple correct solutions, multiple methods of obtaining solutions, the availability of relevant prior experience, and often highly motivating and emotionally involving contingencies (Sternberg et al., 1993, p. 206).

The affordances of online learning technologies have enabled more widespread development of learning environments that facilitate complex problem solving of practical and realistic problems. Moreover, the visual and audio facilities of the web can more fully be utilised to 'set the scene' for the problem, so that learners can be engaged in a problem that is effectively described and appropriately resourced. In this paper, we describe the design of a complex problem embedded within a web environment and facilitated by an onsite excursion for data collection. The learning environment has been designed to deliberately address known problems associated with the approach, specifically in regard to three problem solving strategies, and uses scaffolding prompts and supports embedded within the environment to facilitate student learning.

\section{Weaknesses in problem solving strategies}

Research into the understanding of how learners can benefit from the use of cognitive tools (Jonassen, 1997; 2000) in e-learning environments for the 
improvement of informal reasoning skills has been the focus of several studies in recent years (e.g. Lajoie, Lavigne, Guerra \& Munsie, 2001; Suthers, 1998). A common approach adopted by each of these systems is in the use of visual representational tools, such as concept mapping tools, to facilitate student learning through scaffolds that are designed to develop improved skills in reasoning and argumentation. Outcomes from this work indicate that while many learners were able to develop visual representations that demonstrate evidential relationships between hypotheses, data or evidence in supporting a problem solution, others became confused through making choices that were irrelevant to their specific inquiry.

A previous study by the first author (reported in depth in Brickell, Harper \& Ferry, 2002) into student perceptions of the problem solving process and the strategies used in developing solutions to the problem, revealed several weaknesses that students exhibit in this process. The study introduced four conceptual frameworks (Critical Thinking, Six Thinking Hats, Concept Mapping, Venn Diagrams) for students to use during the problem solving process. The problem context focussed on ill-structured problems presented in a virtual setting on a CD, Exploring the Nardoo (1996). Students assumed the role of environmental consultants who were required to prepare a comprehensive report on environmental problems associated with a fictitious river, within an historical context.

The four frameworks were introduced to participants as a scaffolding mechanism to assist in assessing the credibility of evidence collected to support a solution to the problem; to think strategically; and to make judgments and decisions regarding the effectiveness of proposed solutions. Evaluation of framework use provided some insights into the effectiveness of these strategies in supporting the development of solutions to the problems under investigation and demonstrated that participants using the Six Thinking Hats and Critical Thinking frameworks provided clearer representations of, and better argued solutions to, the problem under investigation.

Throughout the course of this study it became evident that many of the participants from each of the framework groups focused their search and analysis strategies on a preconceived 'solution' to the problem and concentrated their efforts towards this goal. Actions taken by many participants resembled a trial and error approach that lacked any obvious focus towards a particular theory or hypothesis and spent more time accessing resources that had little or no bearing on the specific problem. Figure 1 presents a summary of the problem solving strategies that students would be expected to use in solving the Nardoo problem. The shaded area highlight those aspects of the process that the study confirmed were inadequate or weak, specifically: 
- clarifying the problem,

- checking ideas or theories relating to the problem, and

- refining their ideas throughout the problem solving process (Figure 1).

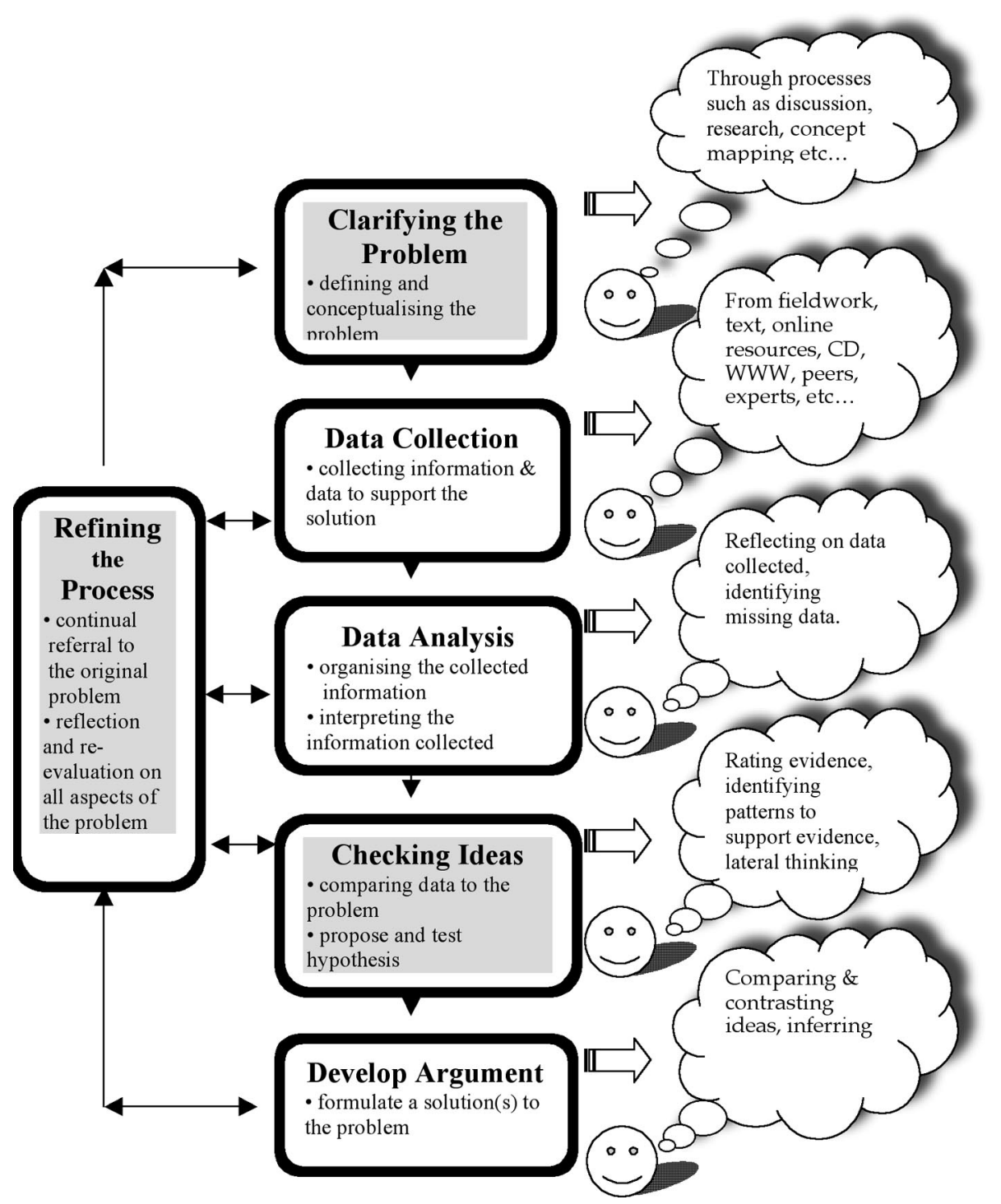

Figure 1: Weaknesses in problem solving strategies 
The results showed that while some aspects of a problem solving approach were enhanced, there were some shortcomings in that many students would approach the problem as they might for well-structured problems, expecting that there was a single answer, or single best approach. Consequently, they were frequently unable to allow for alternative strategies, and were too quick to select and commit to a problem solving strategy without exploring all the options. For example, when being briefed on the problem by the Water Resources Manager, they did not take care to listen to the full description of the task to ensure that they were fully in command of the requirements of the job. Even though the description of the task was given via audio rather than a written document, many students did not take notes or write anything down, but simply moved forward to explore the rest of the environment. Similarly, in the checking phase of the task, many students did not explore alternative solutions, but were more inclined to justify their initial response rather than check carefully to ensure that there was no better solution.

As a result of the findings of this study (see Brickell, et al., 2002 for a more in depth discussion of results) further work has focussed on a design for a scaffolding system to support learners in such environments. It is proposed that in so doing, it may be more appropriate to design structures that:

- Assist learners through the posing of questions that help generate ideas;

- Structure questions that are specific to the context of the problem domain but that remain at a metacognitive level;

- Support the ideas or theories generated through questions that help the learner identify patterns, links and similarities in the data collected.

The proposed scaffolding approach has been incorporated into a learning environment designed to support an excursion visit to Sydney Olympic Park.

\section{The Geography Challenge}

The Geography Challenge is the initial prototype of a long term project (see Brickell \& Herrington, 2004) that has been developed within a collaborative partnership between the Sydney Olympic Park Authority, the NSW Department of Education and Training, the metropolitan Catholic Education Office and the University of Wollongong. The Parklands offer a unique setting for developing educational experiences, promoting the educational, historical, scientific and cultural value of a setting that has undergone extensive remediation in the past ten years. The aim of the collaborative project was to integrate an 'authentic' online environment with a 'traditional' excursion model using a constructivist approach. The design has drawn upon previous work associated with problem solving 
strategies in ill-structured environments, in particular, the problems associated with earlier designs, and scaffolding methods that might successfully counter these problems in the new design.

The Geography Challenge provides a geographic, information rich setting in which students are engaged in investigations that reflect the everyday management of environmental issues that impact on one area of Sydney Olympic Park: the Narawang Wetland. The major objective of this online environment is to address the requirements of the Year 10 Geography syllabus by heightening student awareness of the need to manage the resources of the Narawang Wetland wisely and sustainably through good management practices. The educational approach taken is based on a general constructivist model of learning that challenges students with investigations that are student centred and set within an authentic context. This model of learner engagement views learning as an active and interpretive process that specifically addresses the New South Wales Geography syllabus outcomes:

\footnotetext{
The study of Geography develops a wide range of skills such as gathering, organising and evaluating geographical information from a variety of sources, including fieldwork ... The ecological dimension requires students to identify and analyse the ways humans interact with environments and in so doing develops students' skills in evaluating arguments and problemsolving. (NSW Geography Stage 4/5 syllabus, 2002, p.8)
}

In the scenario presented in the challenge, students are approached by the management of the park to investigate a series of problems associated with pests in the park, the impact of human activity on the parklands, and water management. An engaging animated scenario is presented of annoying mosquitoes biting nearby residents, smelly ponds that deter picnickers and nocturnal rats enjoying the remains of food scraps left by park visitors (Figure 2). The problem is presented in the form of a letter to geography consultants (the students) who are invited to advise the park management on strategies to restore an ecological balance to the area.

In order to complete their assignment, students research the problem, explore and propose a solution, and write their report and recommendations to the park. This process might take several weeks, and the data collection phase is conducted in an onsite visit to the park (i.e., the excursion) mid way through the research.

Development of the model for the Geography Challenge has been guided by situated learning theory of knowledge acquisition where the problem context and tasks require thinking strategies that are appropriate in 'real life' situations and the learning develops as a function of the activity, context and culture in which they occur (Lave \& Wenger, 1991; Brown 
Collins \& Duguid, 1989; Herrington \& Oliver, 2000). Essential elements of this approach to learning emphasise the enhancement of 'higher order' thinking skills through engagement with complex and ill-defined authentic tasks. The growth and application of knowledge to everyday problems requires the consideration of context in which the problem arises since a suitable response takes much of the meaning from the situation being confronted (Choi \& Hannafin, 1995, p. 54).
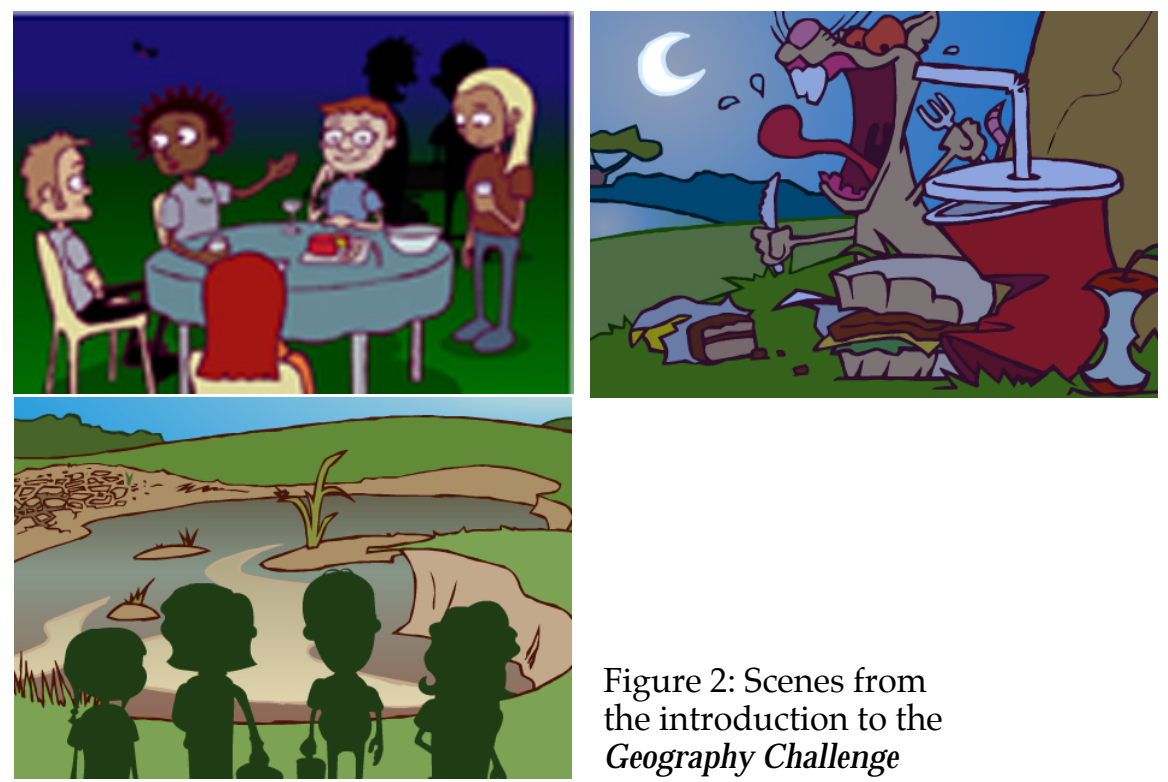

Figure 2: Scenes from the introduction to the Geography Challenge

\section{Authentic problem solving}

The conceptual approach taken in the development of the Geography Challenge was to design a problem based environment where the embedded tasks and activities exhibited characteristics of ill-structured problems (Jonassen, 1997, 2000). These problems:

- appear ill-defined because one or more of the problem elements are unknown or not known with a degree of confidence;

- possess multiple solutions or no solution at all; that is, no consensual agreement on the appropriate solution;

- have no explicit means for determining appropriate actions;

- require learners to express personal opinions or beliefs about the problem; and

- require learners to make judgments about possible problem solutions and defend them. 
Such problems emerge from situations encountered in everyday practice and may require inputs from a number of sources for their resolution. By their very nature, real life, practical problems are often unclear or illstructured situations that require reflective thinking and consideration of multiple perspectives for a successful outcome. Problems of this kind may also be regarded as 'authentic' as they involve coherent, meaningful, and purposeful activities that represent the ordinary practices of the culture, and promote learning that manifests itself through experiences where understanding is developed through continued and situated use (Brown, et al., 1989). The Geography Challenge can be considered to be an authentic environment as it offers engagement in a complex problem where participation in tasks and activities of geographic and environmental processes replicate those within a wider community setting. Learners are provided with a range of the 'culture's' tools, both within the online environment and through field experiences, to afford an opportunity to develop knowledge from the 'expert's' perspective.

Within this online environment the non-linear nature of the information structures and the variety of media formats requires the learner to make decisions about where to find supporting information, what kind of information should be selected to support the task, how much information is needed to justify an argument and what strategy approach is best suited for the problem under investigation. It becomes apparent then that knowledge of one's metacognitive processes, through independent decision making and regulation of learning processes, is necessary for a learner to successfully manage the learning environment. This may require additional support to assist the learner in this process.

\section{Scaffolding}

As a result of the findings from the earlier study (Brickell et al. 2002), scaffolding of student learning appeared to be a key to facilitating those problem solving strategies that appear to be weak or poorly executed.

It has been argued in relation to learner scaffolding, that learners seek new information in ways that depend on, and are limited by, their current mental model and learning goals (Barker et al, 1998; Jonassen, 1997). From observation and interaction with the dynamics of the problem space, learners develop an internal representation of objects, events and relationships among them. As a learner engages with the problem solving task, mental representations are created or enhanced and knowledge transfer, if any, that emerges is driven by the representation formed in the mind of the learner. The nature and quality of the actions that then take place in further development of a problem solution will depend upon the richness of the mental representations that the learner has formed. For 
learners to be successful when developing solutions to complex, illstructured problems they must engage in strategic thinking (Larkin, 1989) which includes use of procedural steps, having strategies for identifying and meeting sub-goals, and using metacognitive strategies for directing, monitoring and evaluating individual learning. Several studies have demonstrated (Lajoie et al, 2001; Suthers, 1998) that learners need to be supported in acquiring these skills.

Traditionally teachers have been the facilitators of learning for their students. Whether this learning has taken place through teacher centred or student centred approaches, the teacher's role has been one of initiating the learning sequence and scaffolding its development through various mechanisms of support. Scaffolding is generally regarded as support for learners while they are engaged in activities just beyond their capabilities (Guzdial, 1994; Hannafin et al, 2001; Vygotsky, 1978). It may range from assisting learners with completion of an entire task to providing occasional support. As the learners' capabilities improve, the teacher gradually reduces the support until the learner becomes self sufficient with the assigned problem. However, the process of continually monitoring the progress of all students becomes increasingly difficult if a more student centred approach is adopted through engagement with complex tasks that involve an inquiry based approach to learning.

In the Geography Challenge scaffolding is provided through supportive teacher facilitation and also in the use of cognitive tools to promote learning. This support provides the bridge across the 'zone of proximal development' (Vygotsky, 1978) - the gap between what the student currently knows and the knowledge needed to accomplish the task. Brush and Saye (2002) provide a differentiation between the two types of support in conceptualising the differences as 'soft scaffolds' - specific support provided by a teacher or peer group member; and 'hard scaffolds' embedded support within the online environment. The construction of understanding through direct human interaction or through use of the online tools provide a means of prompting students in reflecting on and reviewing their 'theories and actions' (Land \& Hannafin, 1997) and work towards providing a bridge between the learners existing cognitive processes and the additional cognitive demands required in understanding the interactions and interrelationships of the problem space.

In the Geography Challenge, online tools have been embedded in the learning environment, specifically: Your Notes, RAP, Resources and Help. Such tools may serve as 'metacognitive coaches' providing hints, 'hard' scaffolds and models to assist the learner to develop skills that facilitate better transfer across domains. The result is a complex interaction between prior knowledge, perceptions of events, intents, actions, observations and 
reflections that lead to further development of on going theories and actions for both the individual and the collaborating members of the investigative group.

Depending on the degree and type of scaffolding required within this online learning environment, the learners may use the support system to assist with the planning process or as part of their ongoing development of higher order thinking skills. Recent work (McGuinness, 2005; Kuhn \& Udell, 2003; White \& Frederikson, 2000) has demonstrated that using aids to induce reflection and other 'higher order' skills promotes clearer understanding when developing interpretations and conclusions based on the evidence collected.

Table 1: Tasks to assist the problem solving process

\begin{tabular}{|c|c|c|}
\hline Engagement phase & $\begin{array}{l}\text { Steps in problem solving } \\
\text { process of Challenge }\end{array}$ & Supporting tasks/activities \\
\hline \multirow[t]{4}{*}{$\begin{array}{l}\text { Pre-visit } \\
\text { Context and } \\
\text { background } \\
\text { development at school } \\
\text { or home }\end{array}$} & $\begin{array}{l}\text { Step 1: } \\
\text { Understanding the } \\
\text { problem }\end{array}$ & $\begin{array}{l}\text { 1. What is a wetland? } \\
\text { 2. Mapping } \\
\text { 3. Climate } \\
\text { 4. Flora and fauna } \\
\text { 5. History }\end{array}$ \\
\hline & $\begin{array}{l}\text { Step 2: } \\
\text { Asking questions }\end{array}$ & $\begin{array}{l}\text { 1. GIS (Geographic Information } \\
\text { System): investigation and } \\
\text { orientation } \\
\text { 2. Pests } \\
\text { 3. Water } \\
\text { 4. Human interaction }\end{array}$ \\
\hline & $\begin{array}{l}\text { Step 3: } \\
\text { Deciding on data } \\
\text { required }\end{array}$ & $\begin{array}{l}\text { 1. Data collection matrix } \\
\text { 2. GIS investigation - field sites }\end{array}$ \\
\hline & $\begin{array}{l}\text { Step 4: } \\
\text { Identifying techniques }\end{array}$ & $\begin{array}{l}\text { 1. Identifying techniques matrix } \\
\text { 2. GIS investigation - field sites }\end{array}$ \\
\hline \multirow{4}{*}{$\begin{array}{l}\text { Fieldwork } \\
\text { On site activities and } \\
\text { data entry at } \\
\text { computer 'Pod' in the } \\
\text { wetland. Secondary } \\
\text { data research through } \\
\text { GIS interaction. } \\
\text { Post-visit } \\
\text { Analysis, reasoning } \\
\text { and argumentation, } \\
\text { development of } \\
\text { artefact at school or } \\
\text { home. }\end{array}$} & $\begin{array}{l}\text { Step 5: } \\
\text { Collecting data }\end{array}$ & $\begin{array}{l}\text { 1. Weather monitoring } \\
\text { 2. Transect } \\
\text { 3. Abiotic testing } \\
\text { 4. Biotic testing } \\
\text { 5. Storm water collection } \\
\text { 6. GIS investigation - secondary } \\
\text { data }\end{array}$ \\
\hline & $\begin{array}{l}\text { Step 6: } \\
\text { Analysing data }\end{array}$ & $\begin{array}{l}\text { 1. GIS investigation - secondary } \\
\text { data } \\
\text { 2. Data comparison with other } \\
\text { groups }\end{array}$ \\
\hline & $\begin{array}{l}\text { Step 7: } \\
\text { Drawing conclusions }\end{array}$ & 1. Opinions of stakeholders \\
\hline & $\begin{array}{l}\text { Step 8: } \\
\text { Reporting your research }\end{array}$ & $\begin{array}{l}\text { 1. Complete research action plan } \\
\text { 2. Complete artefact }\end{array}$ \\
\hline
\end{tabular}


In the Geography Challenge, once students have accepted the offer to act as consultants to Sydney Olympic Park, they choose to investigate one of three themes (Pests, Water, Human Interaction) and work through three phases of engagement: a pre-visit phase; a fieldwork phase and a post-visit phase. Each phase of the investigation is linked to steps in the problem solving process and each step has a range of supporting tasks and activities to support the development of understanding and help develop a broader picture of the complexity of the management issues (Table 1).

By placing learners in the role of professionals who are actually confronted by such problems, they are challenged to develop the knowledge base and strategies that are normally required to resolve the issues.

The tasks and activities associated with each step of the process have been designed to cultivate awareness of the issues, provide the opportunity to retrieve relevant information related to the theme under investigation, promote development of metacognitive skills and facilitate the evolution of reasoning expertise for real world problems. Hints, suggestions and clues are used within each step to refine their knowledge and provide direction for focusing their specific line of inquiry.

Table 2: Development of navigational elements

\begin{tabular}{|c|c|c|}
\hline \begin{tabular}{|c|} 
Problem solving \\
process from model
\end{tabular} & $\begin{array}{l}\text { Research Action Plan } \\
\text { from syllabus }\end{array}$ & $\begin{array}{l}\text { Integration into steps } \\
\text { in Geography Challenge }\end{array}$ \\
\hline $\begin{array}{l}\text { Clarifying the } \\
\text { problem }\end{array}$ & $\begin{array}{l}\text { 1. Identify the aim/purpose of the } \\
\text { investigation. } \\
\text { 2. Generate a number of focus } \\
\text { questions to be addressed by the } \\
\text { investigation. }\end{array}$ & $\begin{array}{l}\text { Step 1: Understand the } \\
\text { problem } \\
\text { Step 2: Asking } \\
\text { questions }\end{array}$ \\
\hline Data collection & $\begin{array}{l}\text { 3. Decide which primary and } \\
\text { secondary data are needed to } \\
\text { answer the focus questions. } \\
\text { 4. Identify the techniques that will be } \\
\text { used to collect the data. } \\
\text { 5. Collect primary, secondary data. }\end{array}$ & $\begin{array}{l}\text { Step 3: Deciding on } \\
\text { the data required } \\
\text { Step 4: Identifying } \\
\text { techniques } \\
\text { Step 5: Collecting data }\end{array}$ \\
\hline Data analysis & $\begin{array}{l}\text { 6. Process and analyse the data } \\
\text { collected. }\end{array}$ & Step 6: Analysing data \\
\hline Checking ideas & & $\begin{array}{l}\text { Step 7: Drawing } \\
\text { conclusions }\end{array}$ \\
\hline $\begin{array}{l}\text { Developing } \\
\text { argument }\end{array}$ & $\begin{array}{l}\text { 7. Select presentation methods to } \\
\text { communicate the research findings } \\
\text { effectively. } \\
\text { 8. Propose individual or group action } \\
\text { in response to the research } \\
\text { findings and, where appropriate, } \\
\text { take such action. }\end{array}$ & $\begin{array}{l}\text { Step 8: Reporting your } \\
\text { research }\end{array}$ \\
\hline
\end{tabular}




\section{Navigational elements}

The Geography syllabus requires students to develop a research action plan (RAP) and provides a framework for students to facilitate this process. In designing the navigational structure for this online environment, the syllabus requirements for developing a research action plan were integrated with the general problem solving strategies developed in the theoretical model.

This integration resulted in the implementation of a sequential series of numerical steps to guide students through their investigations (Table 2). The 'Steps' were then used as the primary navigation system for the Geography Challenge that allows the users to move through the process at their own pace and revisit them as required.

To support the investigation of the themes within the Challenge a series of cognitive tools (Jonassen, 1997; Lajoie, 1993) have been incorporated through a secondary navigational system (Figure 2) of hyperlinks.

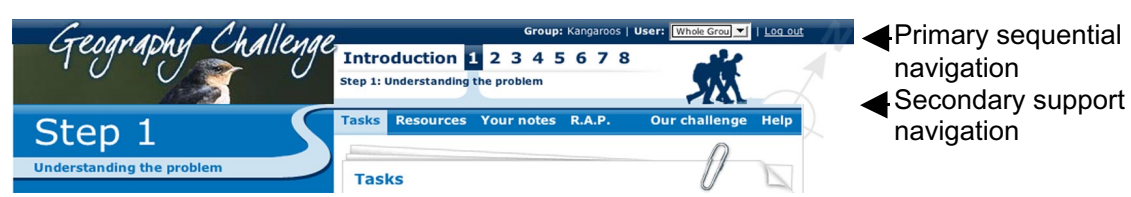

Figure 2: Navigational elements

These links provide access to:

- Tasks - a range of opportunities for students to develop geographic skills while investigating the numerous interactions associated with the overall problem;

- Resources - a range of documents (PDF, Word, Excel) that support each step of the process. An additional feature built within this tool is the availability of a searchable database linked to the online environment.

- Your Notes - a notebook to allow students to record data, write notes, collect source text from within the package as they work towards a problem solution;

- RAP (Research Action Plan) - a tool that allows students to define their plan of action as they work towards a solution. It consists of a series of expandable text boxes that allows students an opportunity to refine data collected and recorded in Your Notes.

- Our Challenge - a link to the introduction of the authentic problem that students encounter when first entering the challenge. This allows ongoing reflection of the initial scenario. 
- Help - the scaffolding system that provides advice on how to address issues presented within the challenge. The scaffolding directs students through the use of cognitive questions and prompts to stimulate their thinking and provide direction as to what course of action they may take within each phase of their Research Action Plan (Figure 3).

Each of the links of this secondary structure of the navigation are step specific and are designed to refine, develop and support the acquisition of students' knowledge.

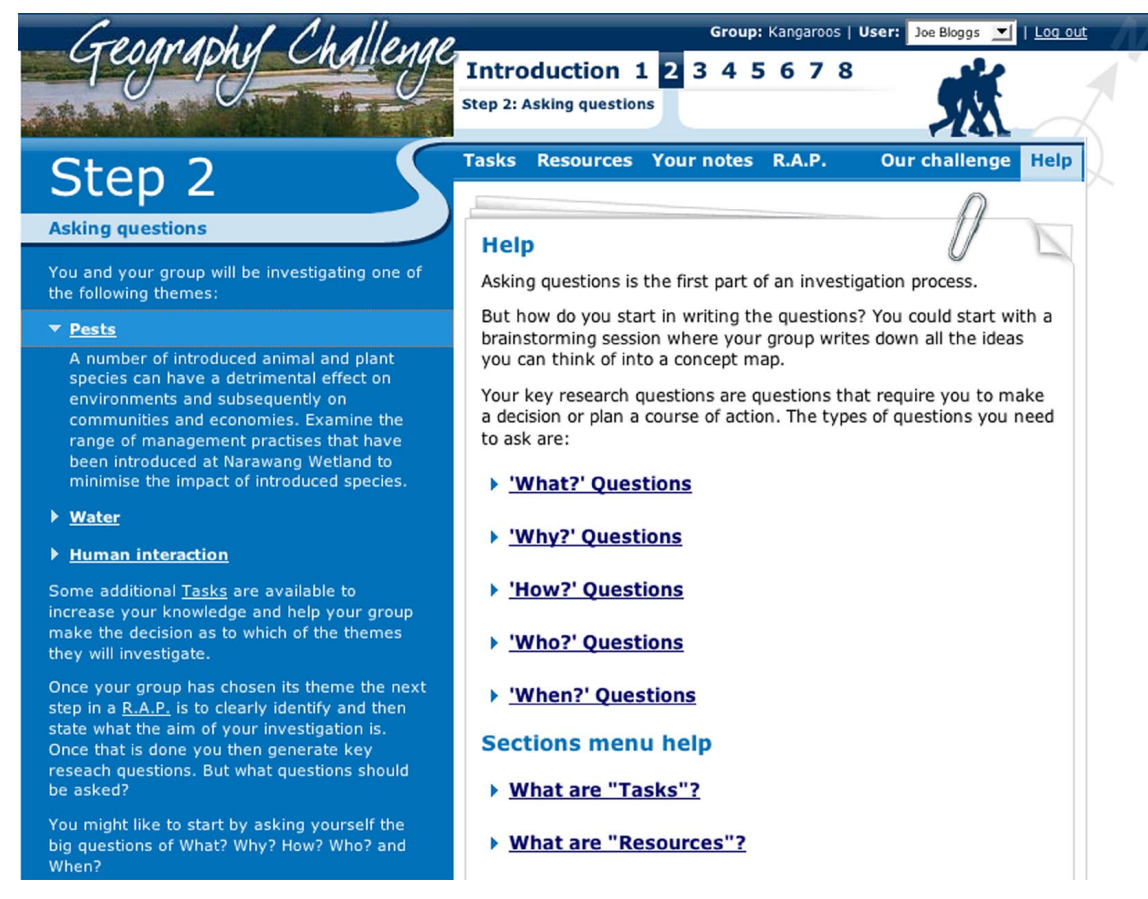

Figure 3: Scaffolding questions in Help

\section{Usability testing}

Formative evaluation was carried out at two local high schools with small groups of students from the target audience during the development. In the initial development phase, a trial in the first of the schools (8 students) confirmed the adequacy of the design approach undertaken, and enabled modifications to be made to the learning environment. The second school trial, in the later stages of development, was undertaken with 17 students to observe them using the Geography Challenge and to conduct focus groups to identify student issues associated with the site. Students worked in 
pairs, but were not given a strict set of tasks to complete, so as to allow them to explore the website in their own way. During this exploration they were asked to complete a survey (12 received), the results of which are tabled below (Table 3).

Table 3: Student survey results

\begin{tabular}{|l|c|c|c|c|}
\hline \multicolumn{1}{|c|}{ Item } & $\begin{array}{c}\text { Strongly } \\
\text { agree }\end{array}$ & Agree & $\begin{array}{c}\text { Dis- } \\
\text { agree }\end{array}$ & $\begin{array}{c}\text { Strongly } \\
\text { disagree }\end{array}$ \\
\hline I found it easy to access and use the web links & 6 & 4 & 0 & 0 \\
\hline $\begin{array}{l}\text { I found the interface (menus, headings, navigation } \\
\text { bars) easy to use }\end{array}$ & 3 & 6 & 1 & 0 \\
\hline I found it easy to access and play the sound files & 2 & 6 & 2 & 0 \\
\hline I found it easy to access linked documents & 3 & 3 & 1 & 0 \\
\hline $\begin{array}{l}\text { The amount of screen explanation was adequate } \\
\text { for performing the task }\end{array}$ & 0 & 6 & 3 & 0 \\
\hline $\begin{array}{l}\text { Terminology was clear and precise } \\
\begin{array}{l}\text { The online materials are useful - it is easy to } \\
\text { understand the relationship between the learning } \\
\text { tasks. }\end{array}\end{array}$ & 1 & 7 & 1 & 0 \\
\hline
\end{tabular}

Following usability testing, students were interviewed (and audio taped) in groups on specific aspects of the design. Students valued the overall appearance of the website, e.g., "It was very informative, easy to read and well set out", and some commented on the authentic nature of Challenge: "It's pretty helpful that this is for real - you had to do it for real", and "Instead of having straight out questions, you learn a lot more." In general the students felt they understood the overall problem they were addressing, although some confusion was evident in their early exploration of the environment, with some students reporting difficulty in "try[ing to] work out what to do ... to try and work out where we had to go and stuff", which is in keeping with the complex nature of the task. However, all were confident that with practice they would feel more capable.

Overall, such evaluation revealed few fundamental or practical problems with the design, and suggested improvements have been incorporated to improve the usability of the Challenge and increase its appeal to the target group. Two schools from the Sydney region are currently undertaking full testing of the beta version, including fieldwork and data entry at Sydney Olympic Park.

\section{Conclusion}

Previous studies of scaffolding using cognitive tools have shown positive results. For example Hollingworth and McLoughlin (2001) used web based scenarios with problem simulations in order to engage learners in problem solving and reflection on their own problem solving strategies. Lajoie 
(1993) conducted a study in avionics troubleshooting, where students were scaffolded with a computer based cognitive tool named Sherlock, which was 'designed to offer the least hint that can enable further problem solving progress ... However, when a trainee can not construct an answer on her own, more elaborate hints are available that support the trainee's problem solving much as a shop supervisor might' (pp. 265-266). A qualitative analysis of students' learning showed that their ability to troubleshoot became more like experts as a result of engaging in the learning environment.

Similarly, the aim of the Geography Challenge is to support students to become more expert like as geographers. It has been designed to reflect a research action plan (required by the NSW Geography syllabus) representing the stages an expert geographer would follow in solving a complex problem involving interaction between humans and the environment. While evaluation has been conducted in the form of project conceptualisation review, needs assessment and formative evaluation during development (including usability studies, expert review and pilot implementation studies) (Reeves \& Hedberg, 2003), it is most likely that only an extensive impact evaluation after full implementation will reveal whether the aims of the project have been realised.

The Geography Challenge has used recent theory and research on problem solving and scaffolding to provide a basis for the design of a complex and realistic task, and to guide the development of scaffolding mechanisms within the environment itself. As such, the design was informed by previous extensive research on a similar learning environment. The scaffolding has been designed to provide metacognitive support for the refining of the process, clarifying the problem and checking of ideas. Further evaluation and research will inform the design of the both the current and future projects featuring cognitive tools in authentic learning environments.

\section{References}

Barker, P., van Schaik, P., Hudson, S. \& Tan, C. M. (1998). Mental models and their role in teaching and learning. In T. Ottmann, \& I. Tomek (Eds). Proceedings of EdMedia/Ed-Telecom 98 World Conference on Educational Multimedia and Hypermedia $\mathcal{E}$ World Conference on Educational Telecommunications (pp.105-110). Virginia: AACE.

Brickell, G. \& Herrington, J. (2004). Learner challenges and situated learning: Engaging students at Sydney Olympic Park. In R. Atkinson, C. McBeath, D. Jonas-Dwyer \& R. Phillips (Eds), Beyond the comfort zone: Proceedings of the 21st ASCILITE Conference (pp. 150-158). Perth, 5-8 December.

http: / / www.ascilite.org.au/ conferences/ perth04/procs/brickell.html 
Brickell, G. J., Ferry, B. \& Harper, B. (2002). Developing informal reasoning skills in ill-structured environments: A case study into problem-solving strategies. In A. Williamson, C. Gunn, A. Young \& T. Clear (Eds), Winds of change in a sea of learning: Proceedings of the 19th Annual ASCILITE conference (pp. 65-73). Auckland, NZ: UNITEC Institute of Technology.

http: / / www.ascilite.org.au/conferences/auckland02/proceedings/ papers/094.pdf

Brown, J. S., Collins, A. \& Duguid, P. (1989). Situated cognition and the culture of learning. Educational Researcher, 18(1), 32-42.

Brush, T. A. \& Saye, J. W. (2002). A summary of research exploring hard and soft scaffolding for teachers and students using a multimedia supported learning environment. The Journal of Interactive Online Learning, 1(2), http: / / www.ncolr.org/jiol/ issues / 2002/ fall/ toc.asp

Choi, J. \& Hannafin, M. (1995). Situated cognition \& learning environments: Roles, structures \& implications for design. Educational Technology Research $\mathcal{E}$ Development, 43(2), 53-69

Cognition and Technology Group at Vanderbilt (1993). Toward integrated curricula: Possibilities from anchored instruction. In M. Rabinowitz (Ed.), Cognitive science foundations of instruction (pp. 33-55). Hillsdale, NJ: Lawrence Erlbaum Associates.

Cole, N. (1990). Conceptions of educational achievement. Educational Researcher, 19(3), 2-7.

Collins, A. (1988). Cognitive apprenticeship and instructional technology (Technical Report No. 6899): BBN Labs Inc., Cambridge, MA.

Guzdial, M. (1994) Software-realized scaffolding to facilitate programming for science learning. Interactive Learning Environments, 4(1), 1-44.

Hannafin, M.J., Hannafin, K.M., McCarthy, J.E. \& Radtke, P. (2001). Scaffolding performance in EPSSs: Bridging theory and practice. In C. Montgomerie \& J. Viteli (Eds), Proceedings of EdMedia World Conference on Educational Multimedia, Hypermedia \& Telecommunications 2001 (pp. 658-661). Tampere, Finland: AACE.

Herrington, J. \& Oliver, R. (2000). An instructional design framework for authentic learning environments. Educational Technology Research \& Development, 48(3), 2348.

Hmelo-Silver, C.E. (2004). Problem-based learning: What and how do students learn? Educational Psychology Review, 16(3), 235-266.

Hollingworth, R. W. \& McLoughlin, C. (2001). Developing science students' metacognitive problem solving skills online. Australian Journal of Educational Technology, 17(1), 50-63. http: / / www.ascilite.org.au/ajet/ajet17/ hollingworth.html

Interactive Multimedia Learning Laboratory (1996). Exploring the Nardoo. [Computer Software]. Belconnen, Australia. Interactive Multimedia Pty Ltd. http: / / www.emlab.uow.edu.au/Nardoo/nardoo.htm

Jonassen, D. H. (1997). Instructional design models for well-structured and illstructured problem-solving learning outcomes. Educational Technology Research $\mathcal{E}$ Development, 45(1), 65-94. 
Jonassen, D. H. (2000). Towards a design theory of problem solving. Educational Technology Research \& Development, 48(1), 63-85.

Jonassen, D. H. (2006). On the role of concepts in learning and instructional design. Educational Technology Research and Development, 54(2), 177-196.

Kuhn, D. \& Udell, W. (2003). The development of argument skills. Child Development, 74(5), 1245-1260.

Lajoie, S. P., Lavigne, N. C., Guerra, C. \& Munsie, S. D. (2001). Constructing knowledge in the context of BioWorld. Instructional Science, 29(2), 155-186.

Lajoie, S.P. (1993). Computer environments as cognitive tools for enhancing learning. In S.P. Lajoie \& S.J. Derry (Eds), Computers as cognitive tools (pp. 261288). Hillsdale, NJ: Lawrence Erlbaum.

Land. S. M. \& Hannafin. M. J. (1997) Patterns of understanding with open-ended learning environments: A qualitative study. Educational Technology Research \& Development. 44(3), 37-53.

Larkin, J. H. (1989). What kind of knowledge transfers? In L.B. Resnick (Ed), Knowing, Learning and Instruction: Essays in Honor of Robert Glaser 283-306. Hillsdale, NJ: Lawrence Erlbaum Associates.

Lave, J. \& Wenger, E. (1991). Situated learning: Legitimate peripheral participation. Massachusetts: Cambridge University Press.

McGuinness, C. (2005). Teaching thinking: Theory and practice. British Journal of Educational Psychology, 11(3), 107-127.

Reeves, T.C. \& Hedberg, J.G. (2003). Interactive learning systems evaluation. Englewood Cliffs, NJ: Educational Technology Publications.

Suthers, D. (1998). Representations for scaffolding collaborative inquiry on illstructured problems. Paper presented at American Educational Research Association. San Diego, CA. [verified 21 Oct 2006] http: / / lilt.ics.hawaii.edu/lilt/ papers/1998/Suthers-aera98.pdf

Sternberg, R.J., Wagner, R.K., \& Okagaki, L. (1993). Practical intelligence: The nature and role of tacit knowledge in work and at school. In J.M. Puckett \& H.W. Reese (Eds), Mechanisms of everyday cognition (pp. 205-227). Hillsdale, NJ: Lawrence Erlbaum Associates.

Vygotsky, L. (1978). Mind in society: The development of higher psychological processes. Cambridge: Harvard University Press.

White, B. \& Frederikson, J. (2000). Metacognitive facilitation: An approach to making scientific inquiry accessible to all. In J. Minstrell \& E. V. Zee (Eds), Inquiry into inquiry learning and teaching in science (pp.283-315). Washington, DC. AAAS. [verified 21 Oct 2006] http: / / thinkertools.soe.berkeley.edu/Pages/paper.html

Dr Gwyn Brickell and Associate Professor Jan Herrington

Research Centre for Interactive Learning Environments

Faculty of Education, University of Wollongong, NSW 2522, Australia

Email: gwyn_brickell@uow.edu.au, Jan_Herrington@uow.edu.au

Web: http:/ / www.uow.edu.au/educ/ 